\title{
APPLICATION OF NANO-SELENIUM IN LAYER DIETS TO IMPROVE THE PRODUCTIVE PERFORMANCE, EGG QUALITY AND IMMUNOLOGICAL TRAITS IN CHICKENS
}

\author{
G. M. Gebriel(1), A. A. EL-Fiky(1), Salwa M. S. Siam(2), E. M. Abou-Elewa(1) \\ and A. M. Hassan ${ }^{(1)}$ \\ (1) Dept. of Poultry and Fish Production, Faculty of Agric., Menoufia Univ., Egypt. \\ (2) Animal Research Institute, Agric. Research Center, Ministry of Agriculture
}

Received: Jun. 11, 2020

Accepted: Jun. 30,2020

ABSTRACT: The experiment was designed to study the effect of dietary Nanoselenium on productive performance, egg quality and immunological traits in laying hens. A total number of $\mathbf{1 8 0}$ laying hens of Silver Montazah strain were used. Layers were divided randomly into six treatments. Five nano-selenium treatment diets with concentrations $(200,160,120,80$ and $40 \mathrm{mg} /$ ton for treatments (T2,T3,T4,T5 and T6), respectively. The treatment (T1) was used as control with $200 \mathrm{mg} /$ ton diet sodium selenite. The results showed that application of nano-selenium in layer diets was effective in increasing egg number and egg mass. Also, nano-selenium improved some immunological traits, feed conversion and some egg quality traits. The optimum level of nano-selenium was $200 \mathrm{mg} /$ ton diet, which recorded $5.40 \mathrm{~g}$ feed $/ \mathrm{g}$ egg mass compared to $9.24 \mathrm{~g}$ feed/ $\mathrm{g}$ egg mass in control treatment $(200 \mathrm{mg} /$ ton diet). Applications of $200 \mathrm{mg} /$ ton diets nano-selenium were significantly decreased, heterophils $(\mathrm{H} \%)$ and $\mathrm{H} / \mathrm{A}$ ratio. Where, Lymphocyte was significantly $(p \leq 0.01)$ increased. Also, there were positive relationship between shell thickness, shell weight (\%) and white blood cells counts with increasing the levels of Nano-selenium in layer diets from $\mathbf{4 0}$ to $200 \mathrm{mg} /$ ton as compared to control.

Key words: Laying hens, Nano-selenium, sodium selenite, productive and immunological traits.

\section{INTRODUCTION}

\section{Egg production traits in layers.}

Little experiments have been done to study the effect of selenium source and levels on some productive traits in chickens. It was reported that egg weight and egg mass significantly increased and feed conversion ratio improved by selenium supplementation as compared with hens fed the control diet (Attia et al., 2010).

However, Rutz et al. (2003) and Skivan et al. (2006) studied the effect of organic (nano-selenium) and inorganic (sodium selenite) selenium supplementation on productive performance in layers. They found that heavier egg weight in organicselenium supplementation hens than control or hens receiving sodium selenite supplemented diets. But, Pavlovi et al. (2009) did not observe any differences in egg production during the first 8 weeks of dietary selenium administration in laying hens. Whereas, in the last 8 weeks selenium yeast increased egg production compared to control and sodium selenite.

Also, Radwan et al. (2015) studied the effect of dietry nano-selenium supplementation on productive performance of laying hens of local strain Silver Montazah. They reported that different levels of sodium selenite or nano-selenium did not affect egg weight and feed intake. While, egg production percentage and egg mass were increased and the feed conversion ratio significantly was improved by adding 
nano-selenium in layer diets. They concluded that supplemental layer diets with $0.25 \mathrm{ppm}$ of nano-selenium was effective in improving the production performance and glutathione peroxidase (GSH-Px) activity of layers.

While, Yan et al. (2016) studied the effect of dietary supplementation of different selenium sources on production performance and antioxidant activity of laying hens. They found that production performance and egg quality of laying hens were not affected by selenium sources.

Recently, Rizk et al. (2017) investigated the effects of different dietary supplementation of different selenium sources of both inorganic (control group at $0.1 \mathrm{mg} / \mathrm{kg}$ diet) and organic selenium (selenium yeast and nano-selenium each at $0.3 \mathrm{mg} / \mathrm{kg}$ diet), on some egg performance trait for Sinai hens during the early laying stage (32 to 34 wk of age). They found that supplementing different selenium sources to the diet, specially nanoselenium had significantly improved all parameters under experimental conditions as compared with control diet. These results indicated that the productive and reproductive performance traits were improved by dietary with different organic selenium (nanoselenium) at $0.3 \mathrm{mg} / \mathrm{kg}$ diet under experimental condition.

More recently, Lu et al. (2019) studied the effect of high dose selenium enriched yeast on laying performance and reported that, there were no statistically significant differences in the mean laying rate of average egg weight and average daily egg mass.

\section{Feed intake $(g /$ d) and feed conversion ratio in layers.}

Little studies have been done on the effect of different nano-selenium levels on both feed intake ( $g / d)$ and feed conversion ratio ( $\mathrm{g}$ feed/ $\mathrm{g}$ egg mass) in layers during the laying period. Sevcikova et al. (2006) and Dlouha et al. (2008) reported that supplementing of diets with organic selenium (nanoselenium) improved feed conversion ratio in broiler chickens.

Also, Stolic et al. (2002), Fu-xiang et al. (2008) and Zhou and Wang (2011) demonstrated that, nano-selenium in broiler diets improved the feed conversion ratio overall the experimental period. In addition, Zhou and Wang (2011) recommended that supplemented $0.3 \mathrm{ppm}$ of nano- selenium in broilers diet was effective in improving feed conversion ratio during the overall experimental period.

In addition, Attia et al. (2010) and Cai et al. (2012) studied the effect of nanoselenium supplementation in layer diets and reported significantly improved the feed conversion ratio compared with hens fed the control diet. Moreover, Radwan et al. (2015) studied the effect of dietary nano-selenium supplementation on productive performance of laying hens. They found that, different selenium levels of sodium selenite or nanoselenium did not affect feed intake, while, the feed conversion ratio significantly improved by adding $0.25 \mathrm{ppm}$ of nanoselenium in layer diets.

Furthermore, the effect of using different forms of selenium at levels of 0.15 or $0.30 \mathrm{ppm}$ in broiler diets on some productive performance were studied by Selim et al. (2015). They reported that using selenium yeast, zinc-Lselenomethionine or nano-selenium at 0.15 or $0.30 \mathrm{ppm}$ over all experimental period improved significantly feed conversion ratio than using inorganic form of selenium. The improvement of feed conversion ratio was $3.1 \%$ during the experimental period. Also, the values 
of feed intake did not affected during the same period.

\section{Egg quality traits during laying period in chickens.}

The effects of dietary nano-selenium supplementation on egg quality traits during laying period (58 wk of age) in layers were studied by some investigators. Early study by Paton et al. (2000) who reported that supplementation of inorganic or organic selenium at $0.3 \mathrm{ppm}$ did not effect on Hough unit values compared with egg laid from hens fed the basal diet.

Conversely, Payne et al. (2005) and Gajcevic et al. (2009) indicated that, egg produced by hen fed a diet with organic selenium had higher Hough unit values than eggs of hens fed the control diet. Also, they reported that, percentage of yolk, albumen and shell weight of eggs were not affected by different levels or sources of selenium.

While, the supplementation of diets with different sources of selenium led to heavier eggs in organic selenium supplemented hens than control or hens receiving sodium selenite supplemented diet (Guido et al., 2013). Also, they found that higher egg shell weight and egg surface area in sodium selenite and selenomethionine (Se Yeast) than control hens. Moreover, the shape index was higher in Se Yeast than in control hens.

However, Radwan et al. (2015) studied the effect of dietary nano-selenium supplementation on productive performance of laying hens. They found that, addition of different levels of sodium selenite or nano-selenium did not affect egg weight and most of egg quality traits. Only, selenium supplementation at 0.40 ppm of nano-selenium or sodium selenite significantly increased yolk index. The highest value of yolk index was recorded for eggs produced by hens fed a diet with 0.40 ppm of Nanoselenium (43.34 vs. 40.96) for control diet. While, Hough unit insignificantly increased by increasing dietary selenium level. The highest value recorded of Hough unit for 0.40 ppm of Nanoselenium was (78.91 vs. 76.25) for control diet, respectively.

On the other hand, Yan et al. (2016) studied the effect of dietary supplementation of different selenium sources on production performance of laying hens. The experiment was conducted to compare the effects of selenium supplementation as forms of sodium selenite (SS), selenium yeast (SY), selenium methionine (SM) or nanoselenium (NS) on egg quality traits in laying hens. They found that egg quality traits of laying hens were not affected by selenium sources.

Similar results were found by Han et al. (2017). They compared the effect of sodium selenite and selenium yeast and their combination on egg quality traits in laying hens. They reported that there were no differences $(P \geq 0.05)$ in egg quality traits between the selenium supplementation diets and the blank control. Similar results were reported by Rizk et al. (2017).

Recently, Lu et al. (2019) reported that, there were no statistically significant differences in any of the external and internal traits of fresh eggs qualities from hen fed different doses of selenium yeast.

\section{Immunological traits of laying hens.}

The primary immune response to Avian Flu Virus $\left(\mathrm{H}_{5} \mathrm{~N}_{1}\right)$ in layers was determined by some investigators. Baowej et al. (2011) studied the effect of selenium supplementation on both cellular and humoral immunity. They reported that, selenium supplementation 
enhanced the organs and cellular immunity, but did not alter the humoral immunity. This may be due to selenium has been shown to stimulate the transformation of T-lymphocytes into cytotoxic cell (Leng et al., 2003). Cytotoxic cells are T-lymphocyte that kills cancer cells.

In addition, Saad et al. (2013) studied the effect of organic or inorganic selenium on the antibody titers against Avian Flu Virus $\left(\mathrm{H}_{5} \mathrm{~N}_{1}\right)$. They reported that the antibody titers against $\mathrm{H}_{5} \mathrm{~N}_{1}$ did not affected by selenium supplementation treatments.

Similar results were reported by Mohapatra et al. (2014), who showed that the antibody titers against $\mathrm{H}_{5} \mathrm{~N}_{1}$. Virus did not affected by different selenium forms or levels diets in layer chickens.

Also, Selim et al. (2015) studied the effect of inclusion inorganic, organic and nano-selenium forms in broiler diets on some immunological traits of broiler chickens. They found that the primary immunity against Avian flu Virus $\left(\mathrm{H}_{5} \mathrm{~N}_{1}\right)$ did not affect the $\mathrm{H}_{5} \mathrm{~N}_{1}$ due to selenium sources or levels. But they recorded significant increase of lymphocyte cells (L\%) and significant decrease of both heterophils $(H \%)$ and $H / L$ ratio by using nano-selenium at levels from 0.15 to 0.30 ppm, compared with inorganic selenium form.

\section{MATERIALS AND METHODS}

The present study was carried out at the Department of Poultry and Fish production, Faculty of Agriculture, Shibin El- Kom, Menoufia University, in addition to Inshas Poultry Research Station, Animal Production Research Institute, Agricultural Research (APRI), with collaboration of Academy of Scientific Research and Technology (ASRT), Egypt. The present work aimed to study the effect of dietary nano- selenium on some economic and immunological traits in laying hens.

\section{Chicken stock.}

Silver Montazah laying hens were used in the present study as Egyptian local developed strain. Silver Montazah strain is a synthetic local strain of chickens, which developed at the, Montazah poultry research station ministry of agriculture, Egypt (Mahmoud et al., 1974).

\section{Birds housing and management.}

Layer were housed in semi-open housing with aground floor system. All birds were treated similarly during the experimental period with a photoperiod length of $16 \mathrm{~h}$ day from 50 weeks of age to the end of experiment at 62 weeks of age.

Feed and water were provided ad libitum through the experimental period.

\section{Experimental design and treatments.}

The present study was carried out at Inshas Poultry Research Station, Animal Production Research Institute, Agricultural Research Center. A total number of 180 females of Silver Montazah laying hens at $\mathbf{5 0}$ weeks old were used. At 50 weeks of age, birds were randomly divided into six treatments, 30 laying hens in each treatment. Then, each treatment subdivided into 3 replicates (10 laying hens/ replicate).

Laying hens were fed a basal diet containing $16.3 \%$ crude protein and 2725 $\mathrm{k}$ cal ME/kg diet. Basal diet containing vitamins and minerals mixture without selenium. A feed was requested from the factory of the Animal Production Research Institute to cover the nutrient requirements for laying hens during experimental periods. The treatments were supplemented with $200 \mathrm{mg}$ 
selenium/ ton diet as sodium selenite for $\mathrm{T}_{1}$ (control treatment), $200 \mathrm{mg}$ nanoselenium /ton diet for $T_{2}, 160 \mathrm{mg} /$ ton diet for $T_{3}, 120 \mathrm{mg} /$ ton diet for $\mathrm{T}_{4}, 80 \mathrm{mg} /$ ton diet for $T_{5}$ and $40 \mathrm{mg} /$ ton diet for $\mathrm{T}_{6}$.

\section{Source and forms of selenium.}

Two forms of selenium were used. First form is sodium selenite which used for control treatment (T1). Second form is nano-selenium which used in treatments (T2, T3, T4, T5 and T6). Selenium forms were obtained from Nano-Tec Company, (Elwahat Road, 6 $^{\text {th }}$ October city, Giza, Egypt). nano-selenium was obtained in liquid form with concentration of 4500 $\mathrm{ppm}$ and in particles around $50 \mathrm{~nm}$ in size.

\section{Mixing of Nano-selenium particles in diet.}

The nano-selenium particles were obtained in liquid form. Five nanoselenium diet concentrations $(200,160$, 120,80 and $40 \mathrm{mg} /$ ton diet for treatments $\left(T_{2}, T_{3}, T_{4}, T_{5}\right.$ and $\left.T_{6}\right)$, respectively. The treatment $\left(T_{1}\right)$ was used as control with $200 \mathrm{mg} /$ ton diet sodium selenite. Treatments were prepared by mixing the selected concentrations of nanoselenium in wheat bran. Samples were mixed well for homogeny and then dried at $60^{\circ} \mathrm{C}$ overnight. The prepared nanoselenium samples in dry form were added to the final layer diet and mixed very well. Treatment birds were fed the nano-selenium diets at $\mathbf{5 0}$ weeks of age to the end of the experiment.

\section{Studied traits.}

The following traits were studied

\subsection{Egg production traits.}

Egg production traits studied were included egg number (EN), average egg weight (EW), and egg mass (EM), which calculated monthly at 54 wk, 58 wk, and 62 weeks of age.

\subsection{Average feed intake of layers.}

The average feed consumption was calculated in grams feed/ bird/ day at 54, 58 and 62 WK of age. The remaining diet was weighed once at the end of each period during the experimental periods.

\subsection{Average feed conversion ratio (FCR) of layers.}

Average feed conversion was calculated as a gram feed consumption divided by gram egg mass ( $g$ feed/ $\mathrm{g}$ egg mass) during the experimental periods at 54,58 and $62 \mathrm{wk}$ of age, according to the following equation:

$$
\mathrm{FCR}=\frac{\text { Feed consumption }(\mathrm{g})}{\text { Egg mass }(\mathrm{g})}
$$

\subsection{Egg quality traits studies.}

Egg quality traits were measured at 58 wk of age in the Physiological Laboratory, Animal Production Research Institute, Agricultural Research Center, Egypt.

Only 6 eggs were randomly taken from each treatment ( 2 eggs from each replicate) which were used for egg quality measurements and to study the external and internal egg quality traits. Both external and internal egg quality traits were studied at $\mathbf{5 8} \mathbf{w k}$ of age as the following.

\subsubsection{External egg quality traits.}

\section{a- Egg weight (EW):}

Eggs were weighed individually to the nearest 0.01 gram by using electronic balance and both egg length and egg diameter were measured by using an Ames (caliper) in millimeters. Then shell weight was detrmined as percentage of egg weight.

\section{b- Egg shape index (E. S. I):}

Egg shape index was determined by using the following formula according to Reddy et al. (1979). 
E. S. I $=\frac{\text { Width of egg }(\mathrm{mm})}{\text { Length of egg }(\mathrm{mm})} \times 100$

\subsubsection{Internal egg quality traits.}

Sample of eggs were weighed and broken on a flat surface where the height of the albumen was measured of half way between the yolk and the edge of the inner thick albumen by using an Ames. The Yolk was separated from the albumen and weighed to the nearest 0.01 g. The following internal quality traits were determined.

\subsubsection{Shell quality traits.}

Egg shell was dried at room temperature for 3 days, then at $60^{\circ} \mathrm{C}$ for 3 days and weighed. The following shell quality traits were determined.

\section{a- Shell weight (S. W):}

Shell weight was determined by using electronic balance to the nearest $0.01 \mathrm{~g}$.

\section{b- Shell percentage (S\%):}

Shell percentage was calculated from the following equation.

$$
\mathrm{S} \%=\frac{\text { Dried shell weight }(\mathrm{g})}{\text { Egg weight }(\mathrm{g})}
$$

\section{c- Shell thickness (S.T.):}

Shell thickness was measured with the membrans in $(\mathrm{mm})$ and determined as the average of three different parts of shell (equator, top and truneate) using micrometer.

\subsubsection{Yolk quality traits.}

a- Yolk weight (Y.W).

Yolk weight was determined individually using electronic balance to the nearest $0.01 \mathrm{~g}$.

b- Yolk percentage (Y\%).

Yolk (\%) was determined by the following equation:

$$
Y(\%)=\frac{\text { Yolk weight }(g)}{\text { Egg weight }(g)} \times 100
$$

c- Yolk height.

Yolk height was determined individually by using an Ames.

d- Yolk index.

Yolk index was determined by using the following formula according to Wells (1968):

$$
\mathrm{Y} 1=\frac{\text { Yolk height }(\mathrm{mm})}{\text { Yolk diameter }(\mathrm{mm})} \times 100
$$

e- Yolk colour.

The egg yolk visual color was determined by matching the yolk with one of the 15 bands of the Roche improved Yolk color fan.

\subsubsection{Albumen quality traits:}

a- Albumen weight (Al. W).

Weight of albumen in grams was calculated by subtracting yolk and dried shell weight from total egg weight as the following.

Al. W. $(g)=$ egg weight - (yolk weight + dried shell weight)

b- Albumen percentage (Al \%)

Albumen percentage was calculated by the following equation:

$$
\text { Al } \%=\frac{\text { Albumen weight }(\mathrm{g})}{\text { Egg weight }(\mathrm{g})} \times 100
$$

\section{C- Albumen height (Al. H):}

Albumen height was measured at half way between the yolk and the edge the enner thick albumen by using an Ames.

\subsubsection{Haugh unit score $(H . U)$.}

Haugh unit score was applied from a special chart using egg weight and albumen height which was measured by using a micrometer according to Haugh (1937) as the following equation:

$$
\begin{aligned}
& \mathrm{H} . \mathrm{U} .=100 \quad 10 \mathrm{~g}\left(\mathrm{H}+7.57-1.7 \mathrm{~W}^{0.37}\right) \\
& \text { Where: } \\
& \mathrm{H} \text { is the albumen height in } \mathrm{mm} . \\
& \mathrm{W} \text { is the egg weight in grams. } \\
& 7.57 \text { and } 1.7 \text { are constants }
\end{aligned}
$$




\subsection{Immunological study.}

The immunological study was carried out at the Animal Health Research Institute, in order to determine the primary immune response to avian flu virus $\left(\mathrm{H}_{5} \mathrm{~N}_{1}\right)$ at 56 wk of age. Layers were subcutaneous injected with $0.5 \mathrm{ml}$ of prepared avian flow virus $\left(\mathrm{H}_{5} \mathrm{~N}_{1}\right)$ at $56 \mathrm{wk}$ of age. Blood samples were drawn individually from each layer (6 samples/ treatment). Immune sera were collected at 14 days post injection. The primary immune response was determined using hemagglutination method. The antibody titer, white blood cells, lymphocyte cells and heterophiles were determined by the Animal Health Research Institute.

\subsection{Statistical analysis.}

Data of productive and immunological traits were subjected to analysis of variance with nano-selenium treatments and their replicate effects using the general linear model procedure of SAS user's Guide (SAS, 2001). Duncan's multiple range tests was used for the multiple comparisons of means (Duncan, 1955).

The statistical model used in the present study was (SAS, 2001)

$$
Y_{i j}=\mu+T_{i}+e_{i j}
$$

Where:

$\mathrm{Y}_{\mathrm{ij}}=$ the observation of the $\mathrm{ij}^{\mathrm{th}}$.

$\mu=$ the common mean.

$T_{i}=$ the fixed effect of the $i^{\text {th }}$ treatments.

$E_{i j}=$ Random error component to be normally distributed.

\section{RESULTS AND DISCUSSION:}

The present experiment aimed to study the application of different selenium (Se) sources and levels to improve productive performance and immunological traits in laying hens. Sodium selenite was used as control $\left(T_{1}\right)$ and five levels of nano-selenium $\left(\mathrm{T}_{2}, \mathrm{~T}_{3}\right.$, $T_{4}, T_{5}$ and $T_{6}$ ) with 200, 160, 120, 80 and $40 \mathrm{mg} /$ ton diets, respectively.

\section{Egg production traits in the whole experimental period.}

The effect of different selenium sources and levels during the whole experimental periods (3 months) on egg production traits in Silver Montazah layers are given in Table (1). The statistical differences among treatments in egg number and egg mass were highly significant ( $p \leq 0.01$ ). But, the statistical differences among treatments in egg weight were not significant.

Table (1): Effect of different selenium (Se) sources and levels during the whole experimental periods ( 3 months) on egg production traits in Silver Montazah layers.

\begin{tabular}{|c|c|c|c|c|c|}
\hline \multirow{2}{*}{ Treatments* $^{*} \begin{array}{c}\text { Se level } \\
\text { mg/ton diet }\end{array}$} & $\begin{array}{c}\text { Egg no } \\
\bar{X} \pm \mathrm{SE}\end{array}$ & $\begin{array}{c}\text { Egg wt }(\mathrm{g}) \\
\bar{X} \pm \mathrm{SE}\end{array}$ & \multicolumn{2}{|c|}{ Egg mass } \\
\cline { 5 - 6 } & 200 & $23.4 \pm 0.10^{\mathrm{d}}$ & $47.0 \pm 1.32$ & $1099.8^{\mathrm{e}}$ & $\begin{array}{c}\text { \% Change of } \\
\text { control }\end{array}$ \\
\hline $\mathrm{T}_{1}$ & 200 & $38.6 \pm 0.61^{\mathrm{a}}$ & $48.3 \pm 1.21$ & $1864.8^{\mathrm{a}}$ & 169.6 \\
\hline $\mathrm{T}_{2}$ & 160 & $34.9 \pm 1.00^{\mathrm{b}}$ & $47.9 \pm 1.02$ & $1671.7^{\mathrm{b}}$ & 152.0 \\
\hline $\mathrm{T}_{3}$ & 120 & $30.0 \pm 1.12^{\mathrm{c}}$ & $47.6 \pm 1.03$ & $1428.0^{\mathrm{c}}$ & 129.8 \\
\hline $\mathrm{T}_{4}$ & 80 & $26.0 \pm 0.95^{\mathrm{d}}$ & $47.5 \pm 1.05$ & $1235.0^{\mathrm{d}}$ & 112.3 \\
\hline $\mathrm{T}_{5}$ & 40 & $19.8 \pm 1.19^{\mathrm{e}}$ & $47.3 \pm 1.12$ & $936.5^{\mathrm{e}}$ & 85.2 \\
\hline $\mathrm{T}_{6}$ & -- & $28.8 \pm 0.98$ & $47.6 \pm 1.15$ & 1427.2 & -- \\
\hline Total Ave. & -- & 0.01 & N.S. & 0.01 & - \\
\hline P-value & & & & \\
\hline
\end{tabular}

${ }^{*} T_{1}=$ Control (Sodium selenite), $T_{2}, T_{3}, T_{4}, T_{5}$ and $T_{6}$ different levels of nano-selenium treatments a, b, c: Means of the same column superscripts differ significantly ( $P \leq 0.05)$. 
The present results showed that nanoselenium diet had higher egg mass than sodium selenite (control) by $69.6,52.0$, $29.8,12.3$ and $5.2 \%$ for $T_{2}, T_{3}, T_{4}, T_{5}$ and $\mathrm{T}_{6}$, respectively.

The present results obtained during the whole experimental period are in good agreement with the results reported by Pavlovi et al. (2009). They found that selenium yeast increased egg production in the last 8 weeks of experimental period as compared to control (sodium selenite). Also, Rizk et al. (2017) found that supplementing different selenium sources to the diets especially nanoselenium had significantly improved the productive and reproductive performance traits at $0.3 \mathbf{~ m g} / \mathbf{~ K g}$ diet nano-selenium.

On the other hand, the present results disagree with the results reported by Attia et al. (2010). They reported that egg production percentages were not affected neither by selenium sources nor levels.

In addition, layers receiving $200 \mathrm{mg}$ nano-selenium/ ton diets significantly had the highest egg number and egg mass. Also, addition of nano-selenium to layer diets improved the egg number and egg mass not only during the whole experimental period, but also by the productive year. Moreover, there were positive relationship between the levels of nano-selenium supplementation in the layer diets with egg number and egg mass. The optimum level of nanoselenium was $200 \mathrm{mg} /$ ton diet, which obtained the highest values of egg number and egg mass under conditions of experiment.

However, supplementation of $200 \mathrm{mg}$ nano-sel ton had higher improvement than the corresponding level of sodium selenite. These differences were related to the different absorption process for
nano-Se than sodium selenite. In this respect, Cai et al. (2012) suggest that the superior performance of nano-se particles may be attributed to their smaller particle size and larger surface area, which increased intestinal absorption and tissue depositions.

\section{Daily feed intake (g/d).}

The effects of different selenium sources and levels during the whole experimental period ( 3 months) on feed intake ( $g / d)$ in Silver Montazah layers are given in Table (2). Results explained that, selenium levels and sources supplementation for layer diets did not significantly affected on the daily feed intake of layers during the whole experimental period (3 months).

The average feed intake for each hen was ranged from 119.1 to $119.8 \mathrm{~g} / \mathrm{d}$ in the first month, from 119.9 to $121.3 \mathrm{~g} / \mathrm{d}$ in the second month, and from 120.9 to $121.9 \mathrm{~g} /$ d for layers in the third month. The average daily feed intake in the third month was higher than in both first and second months. Also, the statistical differences between sources or levels of selenium were not significant.

The present results are in agreement with the findings reported by Cai et al. (2012). They found that increasing of the level of selenium supplementation did not affect feed intake of broilers when increased the concentration (from 0.0 to $2.0 \mathrm{ppm}$ ) of nano-selenium. Also, the differences between sodium selenite and nano-selenium on daily feed intake were not significant (Gouldo et al. 2013).

Recently, Lu et al. (2019) studied the effects of high dose of selenium-enriched yeast on laying performance. They reported that there were no statistically significant differences in the average daily of feed intake in laying hens. 
Table (2): Effect of different selenium (Se) sources and levels during the whole experimental period ( 3 months) on feed intake $(\mathrm{g} / \mathrm{b})$ in Silver Montazah layers.

\begin{tabular}{|c|c|c|c|c|c|c|c|c|c|}
\hline & \multicolumn{2}{|c|}{$\begin{array}{c}\text { Se } \\
\text { level } \\
\text { Treatments* }\end{array}$} & \multicolumn{2}{|c|}{ First month } & \multicolumn{2}{c|}{$\begin{array}{c}\text { Second } \\
\text { month }\end{array}$} & \multicolumn{2}{c|}{ Third month } & \multicolumn{2}{c|}{ Whole Exp-periods } \\
\cline { 3 - 10 } & mg/ton & g/d & $\begin{array}{c}\% \\
\text { change }\end{array}$ & g/d & $\begin{array}{c}\% \\
\text { change }\end{array}$ & g/d & $\begin{array}{c}\% \\
\text { change }\end{array}$ & $\begin{array}{c}\text { G } \\
\text { feed/d }\end{array}$ & \% change** \\
\hline$T_{1}$ & 200 & 119.8 & 100.0 & 121.3 & 100.0 & 121.9 & 100.0 & 121.0 & 100.0 \\
\hline$T_{2}$ & 200 & 118.6 & 99.0 & 119.9 & 98.8 & 121.0 & 99.3 & 119.8 & 99.0 \\
\hline$T_{3}$ & 160 & 119.1 & 99.4 & 120.3 & 99.2 & 121.6 & 99.8 & 120.3 & 99.4 \\
\hline$T_{4}$ & 120 & 119.7 & 99.9 & 121.1 & 99.8 & 121.7 & 99.8 & 120.8 & 99.8 \\
\hline$T_{5}$ & 80 & 119.8 & 100.0 & 120.6 & 99.4 & 120.9 & 99.2 & 120.4 & 99.5 \\
\hline$T_{6}$ & 40 & 119.7 & 99.9 & 121.0 & 99.8 & 121.7 & 99.8 & 120.9 & 99.9 \\
\hline Total Ave. & & 119.5 & -- & 120.7 & -- & 121.5 & -- & 120.5 & -- \\
\hline P-value & & N.S. & -- & N.S. & -- & N.S. & -- & N.S. & - \\
\hline
\end{tabular}

* = Control $\left(T_{1}\right)$ Sodium selenite, where $\left(T_{2}, T_{3}, T_{4}, T_{5}\right.$ and $\left.T_{6}\right)$ are different levels of nano-selenium treatments.

$* *=\%$ Change of control $\left(\mathrm{T}_{1}\right)$.

N.S.: Not significant $(P \leq 0.05)$.

\section{Feed conversion ratio ( $\mathrm{g}$ feed/ $\mathbf{g}$ egg mass):}

The effects of different selenium sources and levels during the whole experimental period (3 months) on feed conversion ( $\mathrm{g}$ feed/ $\mathrm{g}$ egg mass) in Silver Montazah layers are given in Table (3). Results showed that, selenium sources and levels supplementation for layer diets had highly statistical significant differences $(p \leq 0.01)$ on the feed conversion of layers during the whole experimental period (3 month) in Silver Montazah layers.

The average feed conversion ratio was 7.15, 9.40, 12.69 and 9.24 (g feed/ $\mathrm{g}$ egg mass) in the first, second, third months and whole experimental periods, respectively for control treatment (sodium selenite). While in nanoselenium treatments, the feed conversion values had opposite relationship with the nano-selenium levels in layer diets. The average of feed conversion ratio in whole experimental period were $5.40,6.04,7.11$, 8.19 and 10.84 ( $g$ feed/ $g$ egg mass) for $T_{2}$ (200), $T_{3}$ (160), $T_{3}(120), T_{4}(80)$ and $T_{6}$ (40) $\mathrm{mg}$ nano-selenium/ ton diet, respectively.

The present results are in good agreement with findings reports by some investigators. Attia et al. (2010) studied the effect of nano-selenium supplementation in layer diets on feed conversion ratio. They reported that addition of nano-selenium in layer diets improved the feed conversion ratio as compared with layers fed the control diets. Similar results were reported by Radwan et al. (2015). They found that feed conversion ratio significantly improved by adding $0.25 \mathrm{ppm}$ of nanoselenium in layer diets.

On the other hand, the present results disagree with the results reported recently by Lu et al. (2019) in laying hens. 
They found that there were no statistically significant differences in the averages daily of feed intake and feed conversion ratio due to supplementation of high dose of selenium enriched yeast in layer hens.

The present results concluded that adding nano-selenium in layer diets improved feed conversion ratio. The best level of nano-selenium was $200 \mathrm{mg} /$ ton layer diets which recorded $5.40 \mathrm{~g}$ feedl $\mathrm{g}$ egg mass as compared to $9.24 \mathrm{~g}$ feed $\mathrm{g}$ egg mass in control treatment $(200 \mathrm{mg}$ sodium selenitel ton diet).

\section{Egg quality traits in layers.}

Both, external and internal egg quality traits were measured at 58 wk of age (the end of the second month of experimental period). The studied egg quality traits were as the following:

\subsection{External egg quality traits.}

The effects of different selenium source and levels on external egg quality traits in Silver Montazah layers are explained in Table (4). The statistical analysis showed that there were no significant differences in the average egg weight and egg shell index. While, the statistical differences among treatments in both shell thickness $(\mathrm{mm})$ and shell weight $(\%)$ were significant $(p \leq 0.05)$.

The average egg weight was ranged from 48.52 to $50.01(\mathrm{~g})$. The addition of $200 \mathrm{mg}$ nano-selenium Iton had the highest egg weight $(\mathbf{5 0 . 0 1 \mathrm { g } )}$ as compared to $200 \mathrm{mg}$ sodium selenite $/$ ton $(48.89 \mathrm{~g})$, but, the differences were not significant. Also, egg shape index was ranged from 75.40 to 77.08 and the differences were not significant.

Table (3): Effect of different selenium (Se) sources and levels during the whole experimental period on feed conversion ( $g$ feed/g egg mass) in Silver Montazah layers.

\begin{tabular}{|c|c|c|c|c|c|c|c|c|c|}
\hline \multirow{2}{*}{ Treatments* } & \multirow{2}{*}{$\begin{array}{c}\text { Se } \\
\text { level } \\
\text { mg/ton }\end{array}$} & \multicolumn{2}{|c|}{ Fist month } & \multicolumn{2}{|c|}{$\begin{array}{l}\text { Second } \\
\text { month }\end{array}$} & \multicolumn{2}{|c|}{ Third month } & \multicolumn{2}{|c|}{$\begin{array}{l}\text { Whole Exp- } \\
\text { periods }\end{array}$} \\
\hline & & g/d & $\begin{array}{c}\% \\
\text { change }\end{array}$ & g/d & $\begin{array}{c}\% \\
\text { change }\end{array}$ & g/d & $\begin{array}{c}\% \\
\text { change }\end{array}$ & $\begin{array}{c}G \\
\text { feed/d }\end{array}$ & $\begin{array}{c}\% \\
\text { change }\end{array}$ \\
\hline $\mathbf{T}_{1}$ & 200 & $7.15^{d}$ & 100.0 & $9.40^{\mathrm{e}}$ & 100.0 & $12.69^{c}$ & 100.0 & $9.24^{e}$ & 100.0 \\
\hline $\mathbf{T}_{2}$ & 200 & $4.61^{a}$ & 64.5 & $4.48^{a}$ & 45.5 & $8.29^{a}$ & 65.3 & $5.40^{\mathrm{a}}$ & 58.4 \\
\hline$T_{3}$ & 160 & $5.47^{b}$ & 76.5 & $4.64^{a}$ & 49.4 & $9.68^{b}$ & 76.3 & $6.04^{b}$ & 65.4 \\
\hline $\mathbf{T}_{4}$ & 120 & $6.10^{c}$ & 85.3 & $5.42^{b}$ & 57.7 & $12.55^{c}$ & 98.9 & $7.11^{c}$ & 76.9 \\
\hline$T_{5}$ & 80 & $6.53^{c}$ & 93.1 & $7.13^{c}$ & 67.0 & $12.92^{c}$ & 101.8 & $8.19^{d}$ & 88.6 \\
\hline $\mathrm{T}_{6}$ & 40 & $8.43^{e}$ & 117.9 & $8.61^{d}$ & 91.0 & $21.39^{c}$ & 168.6 & $10.84^{f}$ & 117.3 \\
\hline Total Ave. & & 6.38 & -- & 6.61 & -- & 12.91 & -- & 7.80 & -- \\
\hline P-value & & 0.01 & -- & 0.01 & -- & 0.01 & -- & 0.01 & -- \\
\hline
\end{tabular}

* = Control $\left(T_{1}\right)$ Sodium selenite, where $\left(T_{2}, T_{3}, T_{4}, T_{5}\right.$ and $\left.T_{6}\right)$ are different levels of nano-selenium treatments.

** $=\%$ Change of control $\left(\mathrm{T}_{1}\right)$.

$a, b, c=$ Means of the same column superscript differ significantly $(P \leq 0.05)$. 
Application of nano-selenium in layer diets to improve the productive

Table (4): Effect of different selenium sources and levels on external egg quality traits in Silver Montazah layers..

\begin{tabular}{|c|c|c|c|c|c|}
\hline Treatments* & $\begin{array}{c}\text { Se level } \\
\text { mg/ton }\end{array}$ & $\begin{array}{c}\text { Egg } \\
\text { Weight }(\mathrm{g})\end{array}$ & $\begin{array}{c}\text { Shell } \\
\text { thickness } \\
(\mathrm{mm})\end{array}$ & $\begin{array}{c}\text { Egg shell } \\
\text { index }\end{array}$ & Shell wt (\%) \\
\hline $\mathrm{T}_{1}$ & 200 & $48.89 \pm 4.75$ & $0.189 \pm 0.36^{\mathrm{b}}$ & 75.40 & $11.40 \pm 0.61^{\mathrm{b}}$ \\
\hline $\mathrm{T}_{2}$ & 200 & $50.01 \pm 3.17$ & $0.211 \pm 0.31^{\mathrm{a}}$ & 76.09 & $13.29 \pm 0.44^{\mathrm{a}}$ \\
\hline $\mathrm{T}_{3}$ & 160 & $48.72 \pm 3.33$ & $0.209 \pm 0.29^{\mathrm{a}}$ & 75.70 & $13.25 \pm 0.57^{\mathrm{a}}$ \\
\hline $\mathrm{T}_{4}$ & 120 & $46.56 \pm 3.89$ & $0.20 \pm 0.38^{\mathrm{a}}$ & 77.08 & $13.22 \pm 0.61^{\mathrm{a}}$ \\
\hline $\mathrm{T}_{5}$ & 80 & $48.86 \pm 3.86$ & $0.189 \pm 0.31^{\mathrm{b}}$ & 77.07 & $12.78 \pm 0.62^{\mathrm{ab}}$ \\
\hline $\mathrm{T}_{6}$ & 40 & $48.52 \pm 4.58$ & $0.182 \pm 0.30^{\mathrm{b}}$ & 76.33 & $12.33 \pm 0.51^{\mathrm{ab}}$ \\
\hline Total Ave. & -- & $48.59 \pm 4.11$ & $0.197 \pm 0.33$ & 76.28 & $12.71 \pm 0.58$ \\
\hline P-value & -- & N.S. & 0.05 & N.S. & 0.05 \\
\hline
\end{tabular}

* $T_{1}=$ Control (Sodium selenite) $T_{2}, T_{3}, T_{4}, T_{5}$ and $T_{6}$ different levels of nano-selenium treatments. $a, b, c=$ Means of the same column superscripts differ significant $(P \leq 0.05)$.

N.S.: Not significant .

On the other hand, the statistical differences showed significant differences among treatments in both shell thickness $(\mathrm{mm})$ and shell weight percentage $(p \leq 0.05)$ due to the effect of sources and levels of selenium. There was positive relationship between shell thickness and shell weight (\%). Addition of nano-selenium to layer diets with $\mathbf{1 2 0}$ to $200 \mathrm{mg} /$ ton had the highest values of shell thickness and shell weight. Where, addition of $200 \mathrm{mg}$ sodium selenitel ton (control) or 40 to $80 \mathrm{mgl}$ ton nanoselenium to layer diets had the lowest values of both traits (shell thickness and shell weight) percentages.

\subsection{Internal egg quality traits.}

The effects of different selenium sources and levels on internal egg quality traits in Silver Montazah layers are shown in Table (5). The results showed that the statistical differences among treatments in yolk weigh, yolk colour and Hough unit were not significant. While, the statistical differences in albumen weight (\%) and yolk index were significant $(p \leq 0.05)$.
In addition, the average of albumen weight (\%) was ranged from 53.23 to $56.76 \%$. Also, yolk index was ranged from 40.92 to 46.09 . The result showed that yolk index values were increased as the levels of Nano-selenium supplementation increased in layer diets.

In this respect some investigators reported different results about the effect of different selenium sources and levels supplementation on egg quality traits in laying hens. Paton et al. (2000) reported that supplementation of inorganic or organic selenium at $0.3 \mathrm{ppm}$ did not effect on Hough unit values compared with egg laid from hens fed the basal diets. Their findings are in agreement with the findings reported in the present study.

On the other hand, Payne et al. (2005) and Gajeevic et al. (2009) indicated that egg produced by hen fed a diet with organic selenium had higher Hough unit values than of hens fed the control diet. Their findings are disagree with the findings reported in the present study. 
G. M. Gebriel, et al.,

Table (5): Effect of different selenium sources and levels on internal egg quality traits in Silver Montazah layers.

\begin{tabular}{|c|c|c|c|c|c|c|}
\hline Treatments* $^{*}$ & $\begin{array}{c}\text { Se level } \\
\text { mg/ton }\end{array}$ & $\begin{array}{c}\text { Albumen } \\
\text { wt (\%) }\end{array}$ & Yolk wt \% & Yolk index & $\begin{array}{c}\text { Yolk color } \\
\text { score }\end{array}$ & Hough unit \\
\hline $\mathrm{T}_{1}$ & 200 & $56.53^{\mathrm{a}}$ & 32.07 & $42.27^{\mathrm{b}}$ & 6.11 & 77.11 \\
\hline $\mathrm{T}_{2}$ & 200 & $56.76^{\mathrm{a}}$ & 30.01 & $46.09^{\mathrm{a}}$ & 6.25 & 78.67 \\
\hline $\mathrm{T}_{3}$ & 160 & $54.13^{\mathrm{b}}$ & 32.55 & $44.02^{\mathrm{ab}}$ & 5.90 & 78.19 \\
\hline $\mathrm{T}_{4}$ & 120 & $53.23^{\mathrm{b}}$ & 33.55 & $44.08^{\mathrm{ab}}$ & 6.75 & 77.86 \\
\hline $\mathrm{T}_{5}$ & 80 & $55.70^{\mathrm{ab}}$ & 31.52 & $43.18^{\mathrm{b}}$ & 6.01 & 77.61 \\
\hline $\mathrm{T}_{6}$ & 40 & $55.20^{\mathrm{ab}}$ & 32.50 & $40.92^{\mathrm{c}}$ & 6.60 & 77.19 \\
\hline Total Ave. & -- & 55.26 & 32.04 & 43.43 & 6.27 & 76.94 \\
\hline P-value & -- & 0.05 & N.S. & 0.05 & N.S. & N.S. \\
\hline
\end{tabular}

${ }^{*} T_{1}=$ Control (Sodium selenite) $T_{2}, T_{3}, T_{4}, T_{5}$ and $T_{6}$ different levels of nano-selenium treatments. $a, b, c=$ Means of the same column superscripts differ significant $(P \leq 0.05)$.

N.S.: Not significant.

Similar results were reported by Han et al. (2017). They reported that there were no differences in egg quality traits between the selenium supplementation diets and the blank controls. Recently, Lu et al. (2019) reported that there were no significant differences in any of the external and internal traits of fresh egg qualities from hens fed different doses of selenium yeast.

In addition, there were positive relationship between shell thickness and shell weight (\%) due to increasing the levels of nano-selenium in layer diets from 40 to $200 \mathrm{mg} /$ ton as compared to control.

\section{Cellular and humoral immunity to $\mathrm{H}_{5} \mathrm{~N}_{1}$ virus.}

The effect of different selenium sources and levels on some cellular and humoral immunity to $\mathrm{H}_{5} \mathrm{~N}_{1}$, virus in Silver Montazah layers are given in Table (6). The results showed that there were significant differences among treatments in white blood cells counts (WBC $\left.10^{3} / \mathrm{cm}^{3}\right)$, heterophile (H\%), and lymphocyte (L\%). While the statistical differences in humoral immunity to $\mathrm{H}_{5} \mathrm{~N}_{1}$ virus were not significant.

In addition, WBC counts were ranged from 3.70 to $4.36\left(10^{3} / \mathrm{cm}^{3}\right)$ with an average of $3.90 \quad\left(10^{3} \mathrm{l} \mathrm{cm}^{3}\right)$. Supplementation of nano-selenium at 200 $\mathrm{mg} /$ ton diet had the highest WBC counts as compared to control (sodium selenite), which counted (4.36 vs. $\left.3.82 \times 10^{3} / \mathrm{cm}^{3}\right)$ respectively. Also, there were positive relationship between the nano-selenium levels and WBC counts. It was showed that as the levels of nano-selenium increased in the diets, the WBC counts increased.

Also, addition of nano-selenium to the layer diets led to statistical significant increase of lymphocyte (L\%) and significantly decrease of both heterophiles $(H \%)$ and $H / L$ ratio. The percentages of heterophiles were $33.45 \%$ then decreased to $27.41 \%$, as the level of selenium decreased. While, the lymphocyte (\%) showed opposite side which increased as the level of nanoselenium increased. 
Table (6): Effect of different selenium sources and levels on some cellular and humoral immunity to $\mathrm{H}_{5} \mathrm{~N}_{1}$ virus in Silver Montazah layers.

\begin{tabular}{|c|c|c|c|c|c|c|}
\hline \multirow{2}{*}{ Treatments* } & \multirow{2}{*}{$\begin{array}{c}\text { Se level } \\
\mathrm{mg} / \mathrm{ton}\end{array}$} & \multicolumn{4}{|c|}{ Cellular immunity } & $\begin{array}{c}\text { Humoral } \\
\text { immunity }\end{array}$ \\
\cline { 3 - 7 } & & $\begin{array}{c}\mathrm{WBC}^{*} \\
\left(10^{3} / \mathrm{cm}^{3}\right)\end{array}$ & $\mathrm{H}(\%)^{*}$ & $\mathrm{~L}(\%)^{*}$ & $\begin{array}{c}\mathrm{H} / \mathrm{L} \\
\text { ratio }\end{array}$ & $\begin{array}{c}\text { Ab titer } \\
\left(\mathrm{H}_{5} \mathrm{~N}_{1}\right)^{*}\end{array}$ \\
\hline $\mathrm{T}_{1}$ & 200 & $3.82^{\mathrm{b}}$ & $33.45^{\mathrm{a}}$ & $59.86^{\mathrm{c}}$ & $0.56^{\mathrm{b}}$ & $6.01 \pm 0.24$ \\
\hline $\mathrm{T}_{2}$ & 200 & $4.36^{\mathrm{a}}$ & $31.17^{\mathrm{b}}$ & $65.11^{\mathrm{a}}$ & $0.48^{\mathrm{a}}$ & $6.14 \pm 0.21$ \\
\hline $\mathrm{T}_{3}$ & 160 & $3.98^{\mathrm{b}}$ & $30.18^{\mathrm{b}}$ & $64.82^{\mathrm{a}}$ & $0.46^{\mathrm{b}}$ & $6.08 \pm 0.34$ \\
\hline $\mathrm{T}_{4}$ & 120 & $3.83^{\mathrm{b}}$ & $29.76^{\mathrm{bc}}$ & $64.22^{\mathrm{b}}$ & $0.46^{\mathrm{b}}$ & $6.06 \pm 0.34$ \\
\hline $\mathrm{T}_{5}$ & 80 & $3.73^{\mathrm{b}}$ & $28.03^{\mathrm{c}}$ & $64.13^{\mathrm{b}}$ & $0.44^{\mathrm{bc}}$ & $6.17 \pm 0.15$ \\
\hline $\mathrm{T}_{6}$ & 40 & $3.70^{\mathrm{b}}$ & $27.41^{\mathrm{c}}$ & $64.06^{\mathrm{b}}$ & $0.42^{\mathrm{c}}$ & $6.00 \pm 0.17$ \\
\hline Total Ave. & -- & 3.90 & 30.00 & 63.59 & 0.48 & $6.08 \pm 0.24$ \\
\hline P-value & -- & 0.05 & 0.01 & 0.01 & 0.05 & $\mathrm{~N} . \mathrm{S}$. \\
\hline
\end{tabular}

${ }^{*} T_{1}=$ Control (Sodium selenite) $T_{2}, T_{3}, T_{4}, T_{5}$ and $T_{6}$ different levels of nano-selenium treatments. $a, b, c=$ Means of the same column superscripts differ significant $(P \leq 0.05)$, N.S.: Not significant . ${ }^{*}$ WBC $=$ White blood cells,$\quad{ }^{*} \mathbf{H}=$ Heterophile,$\quad{ }^{*} \mathrm{~L}=$ lymphocyte,$\quad{ }^{*}$ Ab titer $=$ Antibody titer against $\mathrm{H}_{5} \mathrm{~N}_{1}$.

On the other hand, results of humoral immunity explained that the antibody titer against $\mathrm{H}_{5} \mathrm{~N}_{1}$, virus did not affected by supplementation of selenium sources or levels. The antibody titers were ranged from 6.00 to 6.17 with an average 6.08 (Table 6).

In this respect, Baowej et al. (2011) studied the effect of selenium supplementation on both cellular and humaral immunity against $\mathrm{H}_{5} \mathrm{~N}_{1}$ virus. They reported that selenium sources inhanced the cellular immunity, but did not alter the humaral immunity. Also, Saad et al. (2013) who reported that the antibody titers agains $\mathrm{H}_{5} \mathrm{~N}_{1}$ virus did not affect by selenium supplementation treatments.

\section{CONCLUSION}

Application of nano-selenium was effective in increasing egg number and egg mass.

Also, it can improving some immunological traits, feed conversion ratio and some egg quality traits.

\section{REFERENCES}

Attia Y.A., A.A. Abdalah, H.S. Zeweil, F. Bovera, A.A. Tag El-Din and M.A. Araft (2010). Effect of inorganic or organic selenium supplementation on productive performance, egg quality and some physiological traits of dualpurpose breeding hens. Czech Journal of Animal Science, 55: 505519.

Baowej, W., H. Guoqing, W. Qiaoli and Y. Bin (2011). Effects of yeast selenium supplementation on the growth performance, meat quality, immunity and antioxidant capacity of goose. $J$. Anim. Physio. and Anim. Nutr., 95: 440-448.

Cai, S.J., C.X. Wu, L. M. Gong, T. Song, H. Wu and L.Y. Zhang (2012). Effects of nano-selenium on performance, meat quality, immune function, oxidation resistance and tissue selenium content in broilers. Poult. Sci., 91: 2532-2539. 
Dlouha, G., S. Sevcikova, A. Dokoupilova, L. Zita, J. Heindl and M. Skrivan (2008). Effect of dietary selenium sources on growth performance, breast muscle selenium, glutathione peroxidase activity and oxidative stability in broilers. Czech Journal of Animal Science, 53: 265-269.

Duncan, D.B. (1955). Multiple range and multiple F-Tests. Biomet., 11:1-42.

Fu-xiang, W., R. Huiying, Z. Fenghua, S. jinquan, J. Jianyang and $L$. Wenli (2008). Effects of Nano- Selenium on the immune Functions and Antioxidant Abilities of Broiler Chickens. Chin. Agric. Sci. Bull., 2: 11.

Gajcevic, Z., G. Kralik, E. Has-Schon and V. Pavic (2009). Effects of organic selenium supplemented to layer diet on table egg freshness and selenium content. Ital. J. Anim. Sci., 8: 189-199.

Gouido, I., A. Gazzl, M. Ferronl, R. Rebucci, A. Fanelli and A. Baldi (2013). Effects of inclusion of seleniumenriched yeast in the diet of laying hens on performance, eggshell quality and selenium tissue deposition. Italian J. Anim. Sci., Vol. 12.

Han, X.J., P. Qin, W.X. Li, Q.G. Ma, G. Ji, J.Y. Zhang and L.H. Zhang (2017). Effect of sodium selenite and selenium yeast on performance of laying hens. Poult. Sci. 96: 3973- 3980.

Haugh, R.R. (1937). The Haugh unit for measuring egg quality. Egg Poultry Mag., 443: 552.

Leng, L., R. Bobcek, S. Kuricova, K. Boldizarova, L. Gresakova, Z. Sevcikova, V. Revajova, M. Levkutova and M. Levkut (2003). Comparative metabolic and immune responses of chickens fed diets containing inorganic selenium and organic selenium. J. Nutr. Sci. Vitaminol., 45: 119-128.

Lu, L. Qu, M.M. Shen, X.G. Wang, J. Guo, Y.P. Hu, T.C. Dou and K.H. Wang
(2019). Effects of high-dose seleniumenriched yeast on laying performance, egg quality, clinical blood parameters, organ development and selenium deposition in laying hens. Poultry Sci., 98: 2522-2530.

Mahmoud, T.H., I.F. Sayed and Y.H. Madkour (1974). The "Silver Montazah" A new Variety of chickens. Agric. Res. Rev., Cairo, 52: 97-105.

Mohapatra, P., R.K. Swain, S.K. Mishra, T. Behera, P. Swain, S.S. Mishra, N.C. Behura, S.C. Sabat, K. Sethy, K. Dhama and P. Jayasankar (2014). Effects of dietary Nano-selenium on tissue selenium deposition, antioxidant status and immune functions in layer chicks. Int. $\mathbf{T}$. Pharmacol., 10: 160-167.

Paton, N. D. A.H. Cantor, A.J. Pescatore and M.J. Ford (2000). Effect of dietary selenium source and levels on internal quality and shell strength of eggs. Poultry Sci., 79 (Suppl-1): 116-

Pavlovi, Z., I. Mileti, Z. Joki and S. Sobaji (2009). The effect of Dietary selenium source and level on hen production and egg selenium concentration. Biol. Trace Elem. Res., 131: 263-270.

Payne, R.L., T.K. Lavergne and L.L. Southern (2005). Effect of inorganic versus orgnic selenium on hen production and egg selenium concentration. Poultry Sci., 84:232237.

Radwan, Nadia. L., T.A. Salah Eldin, A.A. El- Zaial and Mona A.S.A. Mostafa (2015). Effect of dietary Nanoselenium supplementation on selenium content and oxidative stability in table eggs and productive performance of laying hens. Int. I. of poult. Sci., 14(3): 161-176.

Reddy, P.M., V.R. Reddy, C.V. Reddy and P.S.P. Rao (1979). Egg weight, shape index and hatchability in Kaki 
Campbell duck eggs. Ind. J. Poult. Sci., 14: 26-31.

Rizk, Y.S., A.F. Ibrahim, M.K. Mansour, H.S. Mohamed and A.E.M. Soliman (2017). Effect of dietary source of selenium on productive and reproductive performance of sinai laying hens under heat stress conditions. Egypt Poult. Sci, 37 (3):461-489.

Rutz, F., E.A. Pan, G.B. Xavier and M.A. Anciuti (2003). Meeting selenium demands of modern poultry. Responses to Sel- Plex or organic selenium in broiler and breeder diets, pp:147-161, in proc. $19^{\text {Th }}$ Alltech's Annual symp. Nottingham, UK.

Saad, M.B., L.R.S. Gertner, L.N. Kuritza, R.M. Hayashi, L. Pickler and E. Santin (2013). The Effect of Organic Selenium Supplementation on the Broilers' Immune Response. Iranian J. App. Anim. Sci., 3: 113-118.

SAS, Statistical Analysis System, 2001. User's Guide. Version 8.2, SAS Inst. Inc., cary, NC, USA.

Selim, N.A., N.L. Radwan, S.F. Youssef, T.A. Salah Eldin and S. Abou El Wafa (2015). Effect of inclusion inorganic, organic or Nano selenium forms in broiler diets on: 1-Growth performance carcase and meat characteristic. Int. J. Poult.Sci., 14(3) : 135-143.

Seveikova, S., M. Skoivan, G. Dlouha and M. Kouchy (2006). The effect of selenium source on the performance and meat quality of broiler chickens. Czech I. Anim. Sci., 51:449-457.

Skivan, M., I. Simance, G. Dlouha and J. Doucha (2006). Effect of dietary sodium selenite, Se- enriched yeast and Se- enriched chlorella on egg Se concentration, physical parameters of eggs and laying hen production. Czech J. Anim. Sci., 51: 163-167.

Stolic, N., T. Radovanovic N. Stolic, B. Milosevic, M. Milencovic and V. Doscovic (2002). Study of the improviment of the fattening chick feeding quality using organic selenium. Biotechnology in Animal Husbandry. Institute for Animal Husbandry. Belgrade, Yuogoslavia, 18:239-246.

Wells, R.G. (1968). The measurement of certain egg quality characteristics: A Review. In: Egg Quality: A study of the hen's egg (Ed. Carter, T.C.), Oliver and Boyd, Edinburgh, pp: 207-249.

Yan, S.Q., W.S. Geng, Z.H. Jun, Y.H Yuan, W. Jing and Q.G. Hel (2016). Effect of dietary supplementation of different selenium sources on production performance and antioxidant activity of laying hens. Chinese J. Anim. Nut., 28 (4): 1177-1185.

Zhou, X. and Y. Wang (2011). Influence of dietary Nano elemental selenium on growth performance, tissue selenium distribution, meat quality and glutathione peroxides activity in Guangxi Yellow Chicken. Poult. Sci., 90: 680-686. 
استخدام النانو سلينيوم فى علائق البياض لتحسين الأداء الأنتاجى وجودة البيض والصفات المناعية فى الاجاج

جوده محمد جبريل(1)، عبد المنعم عبد الحليم الفقى(1)، سلوى محمود سالم صيام(2)،

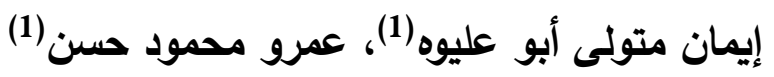

(1) قسم إنتاج الدواجن والأسماك، كلية الزراعة بشبين الكوم، جامعة المنوفية. (2) معهُ بحوث الإنتاج الحيوانى، مركز البحوث الزراعية، وزارة الززاعة.

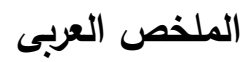

صممت هذه التجربة لاراسة تأثير إضافة جزيئات السيلينيوم النانومترية إلي عليقة الاجاج البياض على كل من

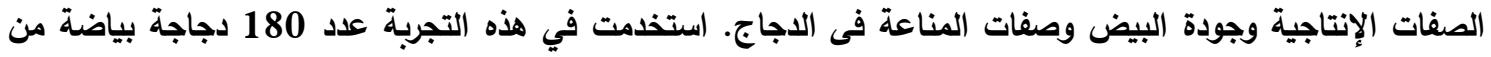

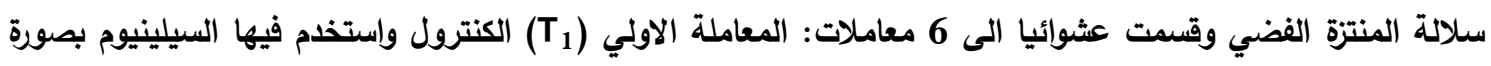
طبيعية بمعدل200 مجم/ طن عليقة من مصدر سيلينات الصوديوم. والمعاملات

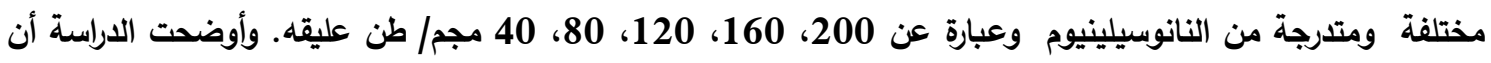

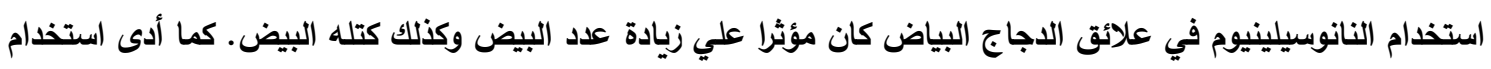

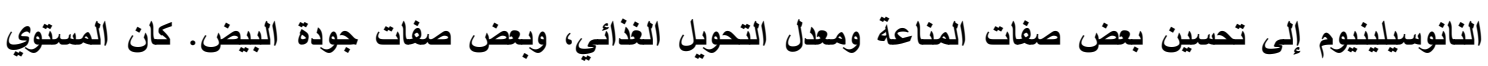
الأمثل من النانوسيلينيوم هو 200 مجم/ طن عليقة حيث سجل أفضل معدل تحول غذائي (5,40 جرام عليقة/ جرام كتلة

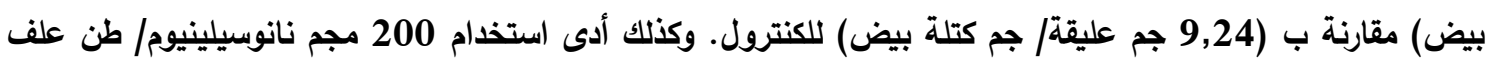

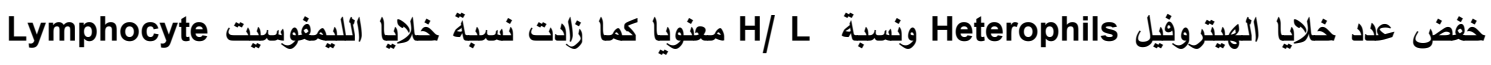

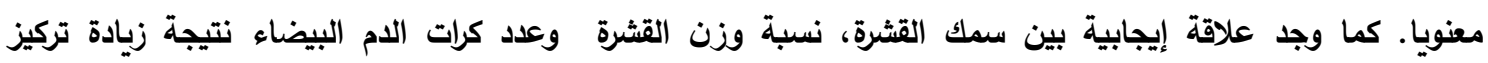
النانوسلينيم فى علائق الاجاج البياض من ولئه بئ 40 إلى 200 مجم/ طن بالمقارنة بالكنترول. 